\title{
POTENSI OBJEK WISATA ALAM HUTAN RAYA, DESA SELAT KECAMATAN SUKASADA, KABUPATEN BULELENG
}

\author{
Luh Putu Budiartini, Ni Desak Made Sri Adnyawati, Cokorda Istri Raka Marsiti \\ Program Studi Pendidikan Kesejahteraan Keluarga, Fakultas Teknik dan Kejuruan \\ Universitas Pendidikan Ganesha \\ Singaraja, Indonesia \\ e-mail : luhputuevibudiartini@gmail.com ,sri.adnyawati@undiksha.ac.id, \\ raka.marsiti@undiksha.ac.id
}

\begin{abstract}
Abstrak
Penelitian ini bertujuan untuk mengetahui potensi objek wisata alam Hutan Raya, Desa Selat Kecamatan Sukasada, Kabupaten Buleleng. Penelitian ini merupakan penelitian deskriptif. Jenis data dalam penelitian ini adalah Data Kualitatif. Pengumpulan data dilakukan melalui metode observasi, metode wawancara dan dokumentasi. Data dianalisis melalui 4 tahap yaitu (1) pengambilan data, (2) reduksi data, (3) penyajian data, (4) penarikan kesimpulan. Hasil dari penelitian ini menunjukkan bahwa objek wisata alam Hutan Raya, Desa Selat, Kecamatan Sukasada, Kabupaten Buleleng telah memenuhi 5 komponen potensi wisata alam yakni (1) Komponen Daya Tarik/atraksi meliputi adanya Bumi Perkemahan, Air Terjun Tukad Basak, wahana selfi, Tracking ke dalam hutan, Monument Mayor Metra, (2) Komponen aksesibilitas meliputi kondisi jalan menuju lokasi objek wisata (3) Komponen amenitas meliputi: tersedianya lahan parkir, warung makan, toilet, dan pos informasi (4) Komponen kelembagaan meliputi: Surat Keterangan Menteri Kehutanan dan Surat Keterangan Bupati Buleleng untuk ijin pengelolaan Hutan Raya, Desa Selat, (5) Komponen lingkungan meliputi sertifikat AMDAL atas keberadaan objek wisata Hutan Raya, Desa Selat
\end{abstract}

Kata Kunci : Potensi, wisata alam, Hutan Raya Desa Selat

\begin{abstract}
This study aims to determine the potential of the natural attractions of Hutan Raya, Selat Village, Sukasada District, Buleleng Regency. This research is a type of descriptive research. the type of data in this study is qualitative data. Data collection is done through observation methods, interview methods and documentation the data is analyzed through 4 stages, namely: (1) data collection, (2) data reduction, (3) data presentation (4) conclusion. The results of this study indicate that natural forest attractions, strait villages, sukasada sub-districts, buleleng regencies have fulfilled 5 components of natural potential, namely (1) pull / pull component attractions include the campsite, Tukad Basak Waterfall, Wahana Selfi, Tracking into the forest, visiting the metra major monument, (2) Accessibility components include the condition of the road to the location of the tourist attraction, (3) The amenities component includes: the availability of parking lots, food stalls, toilets, and information posts, (4) Institutional Components include: Minister of Forestry Certificate and Buleleng Regent Certificate for Greater Forest Management permits, Selat Village, (5) Environmental components include an AMDAL certificate for the existence of a forest tourism object, Selat Village
\end{abstract}

Key Word : Potential, Nature Tourism, Forest, Selat Village 


\section{PENDAHULUAN}

Di Negara maju berwisata merupakan hal yang biasa dilakukan bahkan menjadi kebutuhan hidup bagi setiap orang. Hal inilah yang menggerakan ekonomi pada sektor pariwisata kian berkembang. Melalui Branding Wonderfull Indonesia, peringkat daya saing pariwisata Indonesia terus meningkat. Pada tahun 2013 pariwisata Indonesia menjadi ranking 70 , kemudian di tahun 2015 daya saing pariwisata Indonesia naik ke ranking 50. Indeks daya saing Indonesia kembali melesat ke peringkat 42 pada tahun 2017 (Data ini diambil berdasarkan laporan resmi World Economic Forum, pada tahun 2018). Terkait hal ini, Menteri Pariwisata Arief Yahya menyampaikan bahwa, Indonesia punya target mencapai rangking 30 dunia dan pariwisata akan menjadi penghasil devisa negara terbesar sekaligus menjadi destinasi pariwisata terbaik di tingkat regional serta global.

Indonesia dengan bentangan wilayah yang sangat luas yang didukung sumber daya alam yang beraneka ragam serta berpotensi untuk diolah dan dimanfaatkan. Sektor pariwisata merupakan salah satu sektor yang dapat diandalkan untuk meningkatkan kesejahteraan masyarakat dan pembangunan nasional. Indonesia memiliki berbagai macam potensi pariwisata, baik potensi wisata alam maupun wisata budaya karena Indonesia memiliki bermacam-macam suku, adatistiadat, dan kebudayaan yang karena letak geografis negara Indonesia sebagai negara tropis yang menghasilkan keindahan alam dan satwa (Yoeti, 2008).

Wisata alam merupakan suatu kegiatan perjalanan atau sebagian dari kegiatan tersebut dilakukan secara sukarela serta bersifat sementara untuk menikmati gejala keunikan dan keindahan alam (Direktorat Pemamfaatan Alam dan Jasa Lingkungan, 2002). Wisata alam mulai berkembang sejalan dengan berkurangnya kawasan ekosistem alami di dunia yang didukung oleh semakin meningkatnya kesadaran manusia terhadap lingkungan. Setiap produk wisata alam harus memiliki beberapa komponen penting yaitu (Fandeli, 2002): (1) Atraksi Alam berupa sungai, gunung, hutan, air terjun, (2) Amenitas berkaitan dengan kebutuhan akan fasilitas berupa akomodasi, sanitasi, makanan sehat, pelayanan telpon dan lain sebagainya, (3) Aksesibilitas berkaitan dengan sarana transportasi, (4) Kelembagaan berkaitan dengan adanya koordinasi bagi seluruh stakeholder yang terkait dengan pengembangan objek wisata alam tersebut, (5) Lingkungan berkaitan dengan daya dukung fisik, ekologi, psikologis. Setiap kawasan yang akan dikembangkan menjadi wisata alam terlebih dahulu melakukan analisis daya dukung untuk menghindari terjadinya kerusakan lingkungan yang nantinya dapat menurunkan kualitas Objek Daya Tarik Wisata (ODTW).

Kabupaten Buleleng merupakan salah satu daerah yang secara administratif berada dalam wilayah Provinsi Bali yang memiliki potensi keindahan alam yang luas. Salah satu daerah yang ada di Kabupaten Buleleng yang saat ini sedang mengembangkan potensi wisata alamnya dengan pemamfaatan lahan hutan menjadi sebuah objek wisata yakni berada di Hutan Raya, Desa Selat, Kecamatan Sukasada, Kabupaten Buleleng.

Hutan Raya, Desa Selat merupakan hasil Program Kerja Badan Usaha Milik Desa (BUMDES) Pandan Harum, Desa Selat yang berada dalam pengawasan RPH Kabupaten Buleleng dan Kementerian Kehutanan Provinsi Bali. Pengelolaan kawasan hutan ini di atur dalam Peraturan Hutan Desa No.1 Tahun 2011 tentang Hutan Desa (sumber data dari Rencana Kerja Tahunan Hutan Desa) oleh Direktur BUMDES Pandan Harum, Bapak I Ketut Mangku. Ijin Pengelolaan Hutan Desa (HPHD) diatur dalam Keputusan Menteri Kehutanan Republik Indonesia No. SK. 529/Menhut-II/2010 dan Keputusan Gubernur Bali, Nomor 2017/03-L/HK/2015 tentang Pemberian 
Hak Pengelolaan Hutan Desa di Kawasan Hutan Lindung Seluas \pm 3.041 Hektar kepada 7 (tujuh) lembaga desa di Kabupaten Buleleng, salah satunya BUMDES Pandan Harum, Desa Selat, Kecamatan Sukasada, Kabupaten Buleleng dengan luas area kerja \pm 552 ha untuk pengelolaan kawasan hutan menjadi Objek Wisata Hutan Raya.

Di Hutan Raya Desa Selat ini wisatawan bisa menikmati keindahan alam yakni menikmati panorama laut dan pemandangan kota Singaraja yang sangat indah, menikmati air terjun "Tukad Basak", berkunjung ke monumen mayor metra yang konon katanya sebagai lokasi peperangan pada masa lampau, berkemah, hiking ke hutan di temani tourguide. Wisatawan juga bisa membeli oleh-oleh madu hutan asli Desa Selat hasil budidaya petani lebah madu dan beberapa kerajinan yang di produksi dari hasil hutan di Desa Selat. Di Hutan Raya, Desa Selat juga disediakan beberapa tempat untuk berpoto, tempat ini sering dijadikan sebagai lokasi prawedding. Mengenai sarana dan prasarana di objek wisata ini sudah tersedia aliran listrik, air, toilet, warung makanan dan minuman, pos informasi, serta lahan parkir yang luas. Aksesibilitas jalan menuju objek wisata ini sudah aman karna kondisi jalan yang sudah beraspal. Harga tiket masuk kelokasi wisata ini berkisar Rp. 5000,untuk anak-anak dan Rp. 10.000 untuk dewasa.

Tabel 1.1. Data Kunjungan Wisatawan ke objek Wisata Hutan Raya

\begin{tabular}{l|c|l}
\hline \multicolumn{1}{c|}{ Bulan } & Jumlah & \multicolumn{1}{c}{ Keterangan } \\
\hline Agustus - & 220 & Siswa dari SDN \\
Desember & orang & 3 Selat yang \\
2017 & & melaksanakan \\
& & kegiatan wisata \\
& & alam dan \\
& & pembagian \\
& & raport di Hutan \\
& Raya, Desa \\
& & Selat sebanyak \\
& & 150 orang,dan \\
& & 70 orang \\
& & wisatawan umum \\
& &
\end{tabular}

\begin{tabular}{l|c|l}
\hline $\begin{array}{l}\text { Januari - } \\
\text { Septemb } \\
2018 \\
\text { bulan) }\end{array}$ & orang & $\begin{array}{l}\text { Siswa dari } \\
\text { SMAN 4 } \\
\text { Singaraja yang } \\
\text { melakukan } \\
\text { perkemahan di } \\
\text { Hutan Raya, } \\
\text { Desa Selat } \\
\text { sebanyak 80 } \\
\text { orang, dan 272 } \\
\text { orang } \\
\text { merupakan } \\
\text { wisatawan } \\
\text { umum }\end{array}$ \\
\hline $\begin{array}{l}\text { Oktober } \\
2018- \\
\text { februari }\end{array}$ & orang & $\begin{array}{l}\text { 50 orang } \\
\text { merupakan } \\
\text { wisatawan umum }\end{array}$ \\
\hline
\end{tabular}

(Sumber data: Buku kunjungan wisatawan, BUMDES)

Dari hasil wawancara yang sudah peneliti lakukan, pihak pengelola menyampaikan bahwa target kunjungan perbulannya adalah lebih dari 50 orang, namun pada kenyataanya belum memenuhi target dari pihak pengelola objek wisata oleh sebab itu bisa dikategorikan bahwa tingkat kunjungan wisatawan ke Objek Wisata Hutan Raya, Desa Selat masih rendah.

Berdasarkan latar belakang di atas maka perlu diadakan suatu penelitian yang mampu mengungkap bagaimana potensi alam yang dimiliki oleh Hutan Raya, Desa Selat agar lebih dikenal oleh masyarakat umum, serta akan dilakukan analisis SWOT (Strengths, Weaknesses, Opportunities, and Threats) untuk mengetahui kekuatan, kelemahan, ancaman dalam mengembangkan Potensi alam Objek Wisata Hutan Raya, Desa Selat, Kecamatan Sukasada, Kabupaten Buleleng kedepannya.

Penelitian yang dilakukan oleh I Putu Angganata, menunjukan hasil bahwa (1) kondisi fisik Air Terjun Les berupa ketnggian air terjun 38 meter dengan kedalaman 2 meter dan tempat peristirahatan seluas 1 are; (2) Keadaan lingkungan di sekitar air terjun masih sangat alami; (3) Keunikan Air Terjun Les diantaranya memiliki latar belakang 
perbukitan, dapat dimanfaatkan sebagai tempat yoga dan terdapat toya anakan; (4) Kegiatan yang dapat dilakukan di Air Terjun Les yaitu wisata pemandian dan treeking; (5) Fasilitas penunjang Air Terjun Les yaitu pos informasi, bungalow, tempat parkir dan warung. Berdasarkan hasil penelitian di atas dapat disimpulkan bahwa Air Terjun Les berpotensi sebagai daya tarik wisata alam di kawasan Desa Les, Kecamatan Tejakula, Kabupaten Buleleng

Penelitian Aditya Darmawan yang berjudul "Kajian Potensi Wisata di Desa Munduk, Kecamatan Banjar, Kabupaten Buleleng", Dengan hasil menunjukkan bahwa potensi wisata di Desa Munduk adalah potensi alam, manusia dan budaya. Kajian potensi wisata berdasarkan analisis SWOT yaitu: a) Kekuatan yang cukup besar berupa potensi alam, potensi manusia dan potensi budaya yang beranekaragam, b) Kelemahan potensi wisata Desa Munduk yaitu Potensi alam: Beberapa sarana belum mendukung, karakteristik alam di Desa Munduk pada musim hujan. Potensi manusia: Sumber tenaga kerja sebagai local guide, keterampilan masyarakat seadanya. Potensi budaya yakni belum optimalnya kemampuan pengelolaan atraksi seni dan budaya, belum efektifnya networking diantara para pengelola atraksi seni dan budaya daerah. c) Peluang potensi wisata Desa Munduk yaitu Potensi alam yakni adanya perubahan trend pariwisata, wisatawan lebih menikmati dan menghargai panorama alam pedesaan. Potensi manusia yakni meningkatkan kapasitas bagi pengelola dan pemandu wisata, meningkatnya hubungan kerjasama dengan pelaku wisata. Potensi budaya yakni Desa Munduk beberapa kali ditunjuk dalam Pesta Kesenian Bali, kecenderungan wisatawan Eropa terhadap pariwisata budaya. d) Ancaman yang dapat merusak potensi wisata di Desa Munduk yaitu Potensi alam: Sampah, penebangan pohon, penggunaan air. Potensi manusia yakni sulitnya lapangan pekerjaan, makin berkurangnya nilai budaya gotong royong setiap individu. Potensi budaya yakni masuknya budaya modern dan akulturasi budaya

Penelitian I Made Dwyka Aryawan dengan judul "Potensi Objek Wisata Sejarah di Kota Singaraja" dengan hasil bahwa Kota Singaraja memiliki 3 Objek Bersejarah yaitu Museum Buleleng, Gedong Kirtya, dan Pelabuhan Buleleng yang memiliki potensi sebagai objek wisata sejarah. Adapun potensi tersebut adalah adanya objek yang dapat dilihat (something to see), adanya fasilitas penunjang kegiatan wisata (something to do), adanya sesuatu yang menarik (attraction), dan adanya fasilitas pendukung (amenities). Dapat disimpulkan bahwa objek bersejarah di Kota Singaraja yaitu Museum Buleleng, Gedong Kirtya, Pelabuhan Buleleng memiliki potensi yang baik berdasarkan pada indikator penelitian yaitu adanya objek yang dapat dilihat (something to see), adanya fasilitas penunjang kegiatan wisata (something to do), adanya sesuatu yang menarik (attraction), dan adanya fasilitas pendukung (amenities).

Menurut Sujali (1989:2), mengemukakan pariwisata merupakan kegiatan yang mempunyai tujuan untuk mendapatkan kenikmatan dan kepuasan. Wisata sebagai salah satu aktivitas manusia melibatkan banyak aspek dan dapat ditinjau dari banyak disiplin ilmu. Pariwisata adalah segala sesuatu yang berkenaan dengan wisata, termasuk objek dan daya tarik wisata serta usaha-usaha yang berhubungan dengan penyelenggaraan pariwisata. Inti atau komponen pariwisata yaitu:

a. Atraksi/ attraction : seperti atraksi alam, budaya dan buatan.

b. Amenitas/amenity: berhubungan dengan fasilitas atau akomodasi

c. Aksesibilitas/accebilities berhubungan dengan segala jenis transportasi, jarak atau kemudahan pencapaian. Serta unsur pendukung lainnya (masyarakat, pelaku industri pariwisata, dan institusi pengembangan) yang membentuk sistem yang sinergis dalam menciptakan motivasi kunjungan serta 
totalitas pengalaman kunjungan wisatawan (Kamus Besar Bahasa Indonesia Depdikbud;1995;628)

Potensi wisata adalah berbagai sumber daya yang terdapat di sebuah daerah tertentu yang bisa dikembangkan menjadi daya tarik wisata. Dengan kata lain, potensi wisata adalah berbagai sumber daya yang dimiliki oleh suatu tempat dan dapat dikembangkan menjadi suatu atraksi wisata (tourist attraction) yang dimanfaatkan untuk kepentingan ekonomi dengan tetap memperhatikan aspek- aspek lainnya (Pendit, 2003).

a. Obyek wisata adalah salah satu komponen yang penting dalam industri pariwisata dan salah satu alasan wisatawan melakukan perjalanan (something to see). Di luar negeri obyek wisata disebut tourist attraction (atraksi wisata), sedangkan di Indonesia lebih dikenal dengan objek wisata. Mengenai pengertian objek wisata, kita dapat melihat dari beberapa sumber antara lain: Peraturan Pemerintah No.24/1979: Objek wisata adalah perwujudan dari ciptaan manusia, tata hidup, seni budaya serta sejarah bangsa dan tempat keadaan alam yang mempunyai daya tarik untuk dikunjungi.

b. Surat Keputusan Departemen Pariwisata, Pos dan Telekomunikasi No.KM 98/PW:102/MPPT-87: Objek wisata adalah tempat atau keadaan alam yang memiliki sumber daya wisata yang dibangun dan dikembangkan sehingga mempunyai daya tarik dan diusahakan sebagai tempat yang dikunjungi wisatawan.

Wisata alam adalah sebuah bentuk kegiatan rekreasi dan pariwisata yang memanfaatkan potensi sumberdaya alam, baik itu dalam keadaan alami maupun dalam bentuk budidaya, sehingga memungkinkan para wisatawan agar bisa memperoleh kesegaran jasmaniah maupun rohaniah, manfaat lain dari wisata alam dalam agar bisa mendapatkan pengetahuan dan juga pengalaman serta menumbuhkan inspirasi dan cinta terhadap alam (Anymous, 1982 dalam Saragih, 1993).

Dalam melakukan wisata alam melakukan wisata alami kita harus bisa melestarikan area yang masih alami, dan juga bisa memberikan manfaat secara ekonomi serta mempertahankan kebutuhan budaya masyarakat setempat sehingga bisa menjadi tempat wisata yang memiliki potensi yang dilengkapi dengan fasilitas pendukung seperti alat transportasi atau penginapan. Wisata alam mulai berkembang sejalan dengan berkurangnya kawasan ekosistem alami didunia yang didukung oleh semakin meningkatnya kesadaran manusia terhadap kelestarian lingkungan

Komponen-komponen yang harus di penuhi dalam mengembangkan pariwisata alam adalah (Fandeli, 2002):

a) Komponen atraksi kepariwisataan alam sangat ditentukan oleh keberadaan, perilaku dan sifat dari obyek dan daya tarik alam. Atraksi alam berupa gunung, pantai, sungai, hutan, lembah, ngarai, gua, dan laut mempunyai kondisi, sifat dan perilaku yang harus diperhatikan dalam perencanaan pengembangan obyek dan daya tarik wisata alam.

b) Komponen amenitas berkaitan dengan kebutuhan terahdap fasilitas dan utilitas. Wisatawan akan merasa puas dengan fasilitas dan utilitas apa adanya di alam atau seperti yang dilakukan penduduk setempat. Aspek penunjang dari amenitas adalah kemudahan dalam mendapatkan telpon, kantor pos dan penukaran uang. Hal yang patut mendapatkan perhatian adalah pelayanan yang baik, makanan bergizi sehat, akomodasi yang aman, dan sanitasi yang baik.

c) Komponen aksesibilitas berkaitan dengan sarana transportasi. Tersedianya alat transportasi yang banyak dan beragam serta menjamin keselamatan sangat membantu kelancaran perjalanan wisatawan. Hal yang sangat penting dalam alat transportasi ini adalah jaminan 
keselamatan. Wisatawan sangat peduli terhadap keamanan dan keselamatan diri dalam perjalanan berwisata. Hal ini terutama untuk wisatawan mancanegara.

d) Komponen kelembagaan pengembangan kepariwisataan alam diperlukan koordinasi yang bagus bagi seluruh stakeholder. Adanya keterkaitan yang banyak antar lembaga yaitu mulai dari pengelola obyek, fasilitas, prasarana dan sarana tranportasi, masyarakat dan pemerintah daerah kesemuanya perlu mempunyai visi yang sama. Lembaga pengambil kebijakan baik pusat maupun daerah, seluruh kebijakan harus sejalan dengan visi dan misi dari seluruh pelaku pariwisata.

e) Komponen lingkungan berkaitan dengan daya dukung fisik, ekologi dan psikologis. Oleh karena itu setiap kawasan atau ODTW yang akan dikembangkan menjadi wisata alam terlebih dahulu dilakukan analisis daya dukungnya. Hal ini dimaksudkan untuk menghindari terjadinya kerusakan lingkungan, yang nantinya dapat menurunkan kualitas ODTW.

Analisis SWOT merupakan sebuah alat analisis yang cukup efektif dan efisien serta sebagai alat yang cepat dalam menemukan kemungkinan yang berkaitan dengan pengembangan awal programprogram inovasi baru dalam kepariwisataan. Sifat analisis SWOT sangat situasional, dalam artian hasil analisis tahun sekarang belum tentu akan sama dengan hasil analisis tahun yang akan datang, pengaruh faktor ekonomi, politik, kemanan dan keadaan soial yang melatar belakanginya menyebabkan adanya perubahan. Yoeti (1995: 135) memaparkan bagaimana analisis SWOT dalam skenario pengembangan pariwisata adalah sebagai berikut :

a. Kekuatan (strength): Mengetahui kekuatan pariwisata suatu wilayah, maka dapat dikembangkan sehingga mampu bertahan dalam pasar dan mampu bersaing untuk pengembangan selanjutnya. Dalam hal ini, kekuatan dapat dimanfaatkan secara maksimal untuk meraih peluang.

b. Kelemahan (weakness): Segala faktor yang tidak menguntungkan atau merugikan bagi sektor pariwisata. Pada umumnya, kelemahan-kelemahan yang dapat diidentifikasi adalah kurangnya promosi, jeleknya pelayanan, kurang profesionalnya pelaksana pariwisata di lapangan, terbatasnya kendaraan umum ke objek wisata.

c. Kesempatan (Opportunity) artinya semua kesempatan yang ada sebagai akibat dari kebijakan pemerintah, peraturan yang berlaku, atau kondisi perekonomian

d. Ancaman (Threats) artinya Ancaman dapat berupa hal-hal yang dapat mendatangkan kerugian bagi pariwisata, seperti peraturan yang tidak memberikan kemudahan dalam berusaha, rusaknya lingkungan, dan lain sebagainya.

\section{METODE}

dalam penelitian ini bertujuan menggambarkan suatu keadaan atau fenomena yang terdapat di Objek Wisata Alam Hutan Raya, Desa Selat, Kecamatan Sukasada, Kabupaten Buleleng secara objektif dan berpedoman pada permasalahan yang telah ditetapkan dengan melakukan observasi di lapangan dan wawancara dengan pihak pengelola Objek Wisata Alam Hutan Raya, Desa Selat, Kemudian melakukan pengolahan data dengan mengidentifikasi komponen penting dalam penentuan potensi objek wisata (potensi alam, buatan manusia) dan menganalisis data menggunakan analisis SWOT kemudian membuat simpulan dari fenomena yang terjadi di Objek Wisata Alam Hutan Raya, Desa Selat Kecamatan Sukasada, Kabupaten Buleleng.

Penelitian ini dilakukan di Objek Wisata Hutan Raya, yang berlokasi di Banjar Dinas Sekarsari, Desa Selat, 
Kecamatan Sukasada, Kabupaten Buleleng, Provinsi Bali. Dalam penelitian ini penulis menggunakan penelitian metode kualitatif dan dianalisis lebih lanjut dalam analisis data. Metode penelitian ini berusaha mendiskripsikan objek penelitian berdasarkan data dan fakta yang sebenarnya.

Sumber data adalah segala sesuatu yang dapat memberikan informasi mengenai data. Berdasarkan sumbernya data dibedakan menjadi dua yaitu data primer dan data sekunder. Data primer adalah data yang dibuat oleh peneliti langsung dari sumber pertama atau objek penelitian dalam hal ini data dari hasil observasi langsung ke lokasi penelitian di Hutan Raya, Desa Selat. Data sekunder adalah data yang didapat peneliti dari artikel di internet, jurnal yang di miliki oleh pihak pengelola terkait keberadaan Objek Wisata Hutan Raya, Desa Selat dan hasil wawancara dengan pihak pengelola Objek Wisata Hutan Raya yaitu Badan Usaha Milik Desa (BUMDES) Pandan Harum, Desa Selat.

Metode pengumpulan data yang digunakan dalam penelitian ini adalah: metode observasi, metode wawancara, metode dokumentasi. Analisis data dalam penelitian ini yaitu: (1) pengumpulan data, (2) reduksi data, (3) penyajian data dan (4) penarikan kesimpulan.

\section{PEMBAHASAN}

Objek Wisata Alam Hutan Raya, yang berlokasi di Banjar Dinas Sekarsari, Desa Selat, Kecamatan Sukasada, Kabupaten Buleleng telah memenuhi 5 (lima) komponen yaitu daya tarik, aksesibilitas, amenitas, kelembagaan dan lingkungan sesuai dengan yang diungkapkan oleh Fandeli (2002).

Setelah dilakukan analisis dengan menggunakan SWOT maka didapatkan hasil dari segi kekuatan terdapat Daya Tarik/Atraksi (Attraction) objek wisata alam Hutan Raya, Desa Selat yakni kegiatan wisata yang dapat dilakukan di Objek Wisata Hutan Raya, Desa Selat adalah sebagai berikut: 1) Bumi Perkemahan Hutan Raya, Desa Selat seluas $1 \mathrm{Ha}, 2)$ Mengunjungi Air Terjun Tukad Basak dengan harga tiket Rp. 2000 , 3) Mengunjungi Monumen Bersejarah "Mayor Metra" yang sudah ada sejak jalan penjajahan Belanda, 4) Melakukan Poto Prawedding hanya dengan membayar tiket Rp. 25.000, 5) Melakukan Tracking ke tengah Hutan dengan jarak $1,5 \mathrm{~km}, 6)$ berpoto di Wahana Selfi : Icon Burung Garuda yang terbuat dari anyaman rotan, Rumah Pohon yang terbuat dari bambu rotan dengan tinggi 7 meter dengan kapasitas 3 orang, Jembatan yang terbuat dari bambu seluas $30 \mathrm{~m}^{2}$ dengan kapasitas 6 orang, 7) membeli kerajinan dari rotan yang di anyam menjadi meja dan kursi dan 8) Membeli sarang madu dan madu hutan dengan harga Rp. 150.000/400 ml. Untuk membuat wisatawan semakin tertarik datang mengunjungi Objek Wisata Alam Hutan Raya, Desa Selat maka faktor 1) Kebersihan, 2) Kenyamanan dan 3) Keamanan adalah hal penting yang harus dipenuhi oleh Objek Wisata Alam Hutan Raya, Desa Selat.

Kondisi aksesibilitas di Objek Wisata Alam Hutan Raya, Desa Selat di perhatikan dari kondisi jalan sudah termasuk jalan yang beraspal, terdapat beberapa tikungan yang tajam serta lebar jalan 3 meter jadi wisatawan bisa mengendarai sepeda motor maupun mobil. Dalam komponen amenitas terdapat beberapa sarana dan prasarana yang disediakan di Objek Wisata Alam Hutan Raya, Desa Selat yaitu: 1) Lahan Parkir yang luas, 2) Warung makan yang menyediakan makanan ringan, bakso ayam, sate kambing, tipat catok, rujak, minuman dan lainnya, 3) MCK/ Toilet dan 4) Pos Informasi yang juga digunakan sebagai tempat pembelian tiket masuk objek wisata, dan melayani informasi yang diperlukan oleh wisatawan.

Pada komponen kelembagaan, Objek Wisata Alam Hutan Raya, Desa Selat telah memenuhi persyaratan dengan mendapatkan ijin pengelolaan dari Menteri Kehutanan Republik Indonesia yang di atur dalam Keputusan Menteri Kehutanan 
Republik Indoneisa Nomor: SK.629/Menhut-II/2010 Tentang Penetapan Kawasan sebagai areal kerja Hutan Desa seluas \pm 3.014 Hektar di Kabupaten Buleleng, Provinsi Bali, dan diantaranya \pm 552 Hektar dalam kawasan Hutan Desa, Desa Selat, Kecamatan Sukasada, Kabupaten Buleleng, Bali yang diterbitkan pada tangga 30 Oktober 2015, Serta mendapatkan ijin pengelolaan dari Pemerintahan Kabupaten Buleleng dengan dikeluarkanya Surat Keterangan Bupati Buleleng pada bulan September 2016.

Pada komponen lingkungan, pihak pengelola Objek Wisata Alam Hutan Raya, Desa Selat sedang dalam proses menunggu dikeluarkannya sertifikat resmi Analisis Mengenai Dampak Lingkungan (AMDAL). Pihak Badan Usaha Milik Desa (BUMDES) Pandan Harum, Desa Selat dalam wawancara tanggal 19 februari 2019 menyatakan bahwa pengelolaan Objek Wisata Alam Hutan Raya, Desa Selat mengacu pada peraturan yang berlaku mengenai norma dan pengelolaan hutan desa yang diatur dalam Peraturan Menteri LHK No.P.83/Menlhk/2016 tentang perhutanan sosial dan dijabarkan melalui Perdirjen PSKL No. P.16 Tahun 2016 tentang Pedoman Penyusunan Rencana Pengelolaan Hutan Desa, Rencana Kerja Usaha, Izin Usaha Pemanfaatan Hutan Kemasyarakatan dan rencana Kerja Usaha Izin Usaha Pemanfaatan Hasil Hutan Kayu Hutan Tanaman Rakyat dan Perdirjen PDASHL No.P.6 2016 tentang Pedoman Penyusunan Design Tapak Pengelolaan Pariwisata Alam di Hutan Lindung.

Berdasarkan 5 (lima) Komponen yang sudah terpenuhi di atas, keberadaan Objek Wisata Alam Hutan Raya, Desa Selat ini merupakan kekuatan (Strength) yang harus dikembangkan agar lebih memiliki mamfaat lebih kedepannya bagi dunia pariwisata dan masyarakat seitar.

Namun Setelah dilakukan analisis didapatkan hasil bahwa Objek Wisata Alam Hutan Raya, Desa Selat memiliki beberapa kelemahan (Weakness) yaitu: (1) Promosi obyek wisata yang masih kurang, karena selama ini promosi hanya dari mulut ke mulut, tidak ada promosi objek wisata melalui internet, sosial media yang lebih luas, tidak adanya kerjasama yang kuat antar pengelola dengan beberapa pelaku wisata di Kabupaten Buleleng, tidak adanya penyebaran brosur promosi objek wisata hutan raya, Desa Selat menyebabkan ketidaktahuan masyarakat akan potensi wisata ini, oleh sebab itu peneliti memberikan solusi dengan membuatkan channel youtube yang dapat diakses melalui https://youtu.be/iXiw3bRcmSc (Channel: Luh Putu Evi Budiartini), (2) Keterbatasan anggaran untuk biaya pemeliharaan sarana dan prasarana obyek wisata juga menjadi kelemahan untuk pengembangan objek wisata kedepannya, oleh sebab itu peneliti memberikan masukan agar harga tiket masuk menuju objek wisata bisa dinaikkan mengingat potensi objek wisata Hutan Raya yang sangat potensial. (3) Tidak tersedianya tenda dan perlengkapan berkemah sehingga wisatawan yang ingin berkemah harus membawa perlengkapan tenda langsung, hal tersebut juga bisa menjadi ancaman untuk pengembangan bumi perkemahan Hutan Raya, Desa Selat kedepannya, (4) Tidak tersedianya langsung hasil kerajinan rotan dan madu di lokasi objek wisata membuat wisatawan tidak mengetahui bahwa di Objek Wisata alam Hutan Raya, Desa Selat tersedia kerajinan rotan dan madu hutan

Selain kelemahan, dari hasil analisis juga terdapat ancaman (Threat) dalam pengelolaan Objek Wisata Hutan Raya, Desa Selat yakni saat musim kering menyebabkan beberapa tanaman dan rumput juga ikut mengering sehingga mengurangi keasrian dan keindahan objek wisata. Adanya kelemahan (Weakness) dan ancaman (Threat) yang ada saat ini bisa membuat potensi besar objek wisata alam Hutan Raya, Desa Selat semakin tidak diketahui oleh masyarakat luas yang pada akhirnya bisa menyebabkan terhentinya pengelolaan dan tidak bisa dikembangkan lagi kedepannya.

Dengan memaksimalkan Kekuatan (Strength) yang dimiliki oleh Objek Wisata 
Alam Hutan Raya, Desa Selat serta mencarikan solusi terhadap beberapa kelemahan, maka dengan begitu akan menambah peluang (Opportunity) yang ada saat ini untuk dimamfaatkan yakni: 1) Menjadikan Obyek Wisata Hutan Raya, Desa Selat menjadi lokasi kunjungan wisata bagi pelajar agar lebih mengenal dan mencintai alam 2) Dengan berkembangnya Objek Wisata Alam, Hutan Raya diharapkan dapat menciptakan kesempatan kerja bagi warga disekitar kawasan objek wisata seperti: Tukang Parkir, Petugas Kebersihan, Penjaga Wahana, Tourguide, petugas keamanan, terbukanya lahan usaha bagi warga yang ingin berjualan makanan, minuman maupun souvenir dan lain sebagainya.

\section{SIMPULAN}

Berdasarkan paparan pada bab hasil dan pembahasan Potensi Objek Wisata Alam Hutan Raya, Desa Selat, Kecamatan Sukasada, Kabupaten Buleleng dapat disimpulkan bahwa Objek Wisata Alam Hutan Raya, Desa Selat telah memenuhi 5 komponen penting dalam wisata alam yakni: Daya Tarik, Aksesibilitas, Amenitas, Kelembagaan dan Lingkungan.

1. Pada Komponen Daya Tarik meliputi: adanya kegiatan yang dapat dilakukan wisatawan yaitu berkemah di Bumi Perkemahan Hutan Raya, mengunjungi air terjun Tukad Basak, berpoto di wahana selfi (icon burung garuda, rumah pohon dan jembatan bambu), mengunjungi monumen "Mayor Metra", melakukan tracking kehutan, membeli madu dan kerajinan anyaman rotan. Kebersihan, keamanan dan kenyamanan di objek wisata alam Hutan Raya, Desa Selat sudah terjaga dengan baik.

2. Pada Komponen aksesibilitas meliputi jarak tempuh menuju lokasi Objek Wisata Hutan Raya, Desa Selat yakni 30 menit dari Kota Singaraja.

3. Pada Komponen Amenitas terdapat sarana dan prasarana yang meliputi: lahan Parkir, warung makan, MCK dan Pos informasi.

4. Pada Komponen kelembagaan objek wisata alam Hutan Raya, Desa Selat telah mendapatkan SK Menteri Kehutanan dan SK Bupati Buleleng untuk pengelolaan objek wisata.

5. Pada Komponen lingkungan saat ini pihak pengelola sudah mengurus sertifikat untuk AMDAL (analisis mengenai dampak lingkunga) atas keberadaan Objek Wisata Hutan Raya, Desa Selat

\section{SARAN}

Adapun saran dari penelitian ini adalah:

a. Menjaga kebersihan Obyek Wisata Alam Hutan Raya, Desa Selat lokasi tersebut tidak tercemar dan melestarikan alam yang ada di sekitar lokasi obyek wisata dengan tidak menebang pohon sembarangan untuk mengurangi bencana alam.

b. Pengelola dapat melakukan kerjasama dengan masyarakat dan dengan pemerintah Kabupaten Buleleng dan Dinas Pariwisata untuk melakukan pemasaran ataupun promosi terkait dengan lokasi wisata baik melalui media massa, lembaga penelitian, internet maupun televisi.

\section{DAFTAR RUJUKAN}

Angganata, I Putu. 2017. "Potensi Wisata Air Terjun Les Sebagai Daya Tarik Wisata Alam Di Kawasan Desa Les, Kecamatan Tejakula, Kabupaten Buleleng" Jurnal Bosaparis. Volume 7, Nomor 1, Tahun 2017

Darmawan, Aditya. 2017 "Kajian Potensi Wisata Di Desa Munduk, Kecamatan Banjar, Kabupaten Buleleng" Jurnal Bosaparis. Volume 7, Nomor 1, Tahun 2017

Dwyka Aryawan, I Made. 2017. "Potensi Objek Wisata Sejarah Di Kota Singaraja" Jurnal Bosaparis. Volume 8, Nomor 2, Tahun 2017 
Jurnal Bosaparis: Pendidikan Kesejahteraan Keluarga

Volume 10, Nomor 1, Maret 2019

Fandeli, Chafid. 1995. Dasar-Dasar Manajemen Kepariwisataan Alam. Yogyakarta: Liberti.

Fandeli, Chafid. 2002. Pengembangan Ekowisata dengan Paradigma Pengusaha Ekowisata. Fakultas Kehutanan Universitas Gadjah Mada, Yogyakarta.

Pendit S, Nyoman. 1987. IImu Kepariwisataan: Suatu Pengantar Perdana. Jakarta: Pradnya Paramita.

Sujali, 1989. Geografi Pariwisata Dan Kepariwisataan. Yogyakarta: Fakultas Geografi Univeresitas Gadjah Mada.

Sugiyono, 2008. Metode Penelitian Pendidikan, Pendekatan Kuantitatif, Kualitatif, dan $R \& D$. Bandung: Alfabet.

Suwantoro, Gamal. 2004. Dasar-Dasar Pariwisata. Yogyakarta: Andi

Yoeti, Oka A. 1996. Pengantar IImu Pariwisata. Bandung: Angkasa

Yoeti, Oka A. 1995. Anatomi Pariwisata. Bandung: Angkasa

Yoeti, Oka A. 1995. Penuntun Praktis Pramuwisata Professional : Angkasa 